\title{
RESTLESS DREAMS AND SHATTERED MEMORIES: PSYCHOANALYSIS AND SILENT HILL
}

\author{
EWAN KIRKLAND \\ University of Brighton \\ e.kirkland@brighton.ac.uk
}

Recibido: 25-01-2015

Aceptado: 18-05-2015

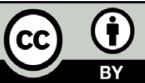

\section{Abstract}

This paper applies psychoanalytic frameworks to the survival horror franchise Silent Hill, a series which is itself informed by psychoanalytic themes. Concerns include the construction of game space as maternal womb, cinematic sequences as primal fantasies, and the representation of memory across the games within a psychoanalytic context. The horror genres' preoccupation with monstrous mother figures is evident in boss battle adversaries, the depiction of gamespaces as bloody "maternal caves», and in narratives concerning characters' searching for their parental origins Distinguishing between videogames' playable sequences and cinematics as conscious and sub-conscious aspects, cut-scenes are analysed as reproducing primal fantasies, serving to explain protagonists' backstory and situating play within narrative contexts. Such moments intrude into the game, marking transformations between the ordinary world and the abject Otherworld, or heralding the emergence of psychoanalytically-resonant monstrous creatures which the protagonist must destroy. Finally, Silent Hill: Shattered Memories is examined as a game which, even more than others, foregrounds the series' explicit reference to psychoanalytic preoccupations, engaging with contemporary understandings concerning the relationship between memory, media and fantasy.

KeYwORDs: Silent Hill, survival horror, psychoanalysis, videogames, memory.

\section{RESUMEN}

En el presente artículo se aplica el marco de estudio psicoanalítico a la serie de survival horror Silent Hill, ella misma basada en temas psicoanalíticos. Entre los asuntos tratados cabe mencionar la construcción del espacio del juego como un vientre materno, las 
secuencias cinemáticas como fantasías originarias (Urphantasien), así como la representación de la memoria durante las partidas en un contexto psicoanalítico. El interés del género de terror por las figuras maternas monstruosas es evidente en los adversarios que combate el jefe, en la descripción de los espacios del juego como sangrientas «cuevas maternales» y en los relatos sobre la búsqueda que emprenden los personajes para hallar su ascendencia. Distinguiendo entre secuencias jugables de videojuegos y secuencias cinemáticas como aspectos conscientes e inconscientes, las cinemáticas son analizadas como reproducciones de fantasías originarias que sirven para explicar el pasado de los protagonistas y emplazar el juego en contextos narrativos. Tales elementos irrumpen en la partida, señalando el paso del mundo ordinario al abyecto Más Allá (y viceversa) o anunciando la aparición de monstruosas criaturas de resonancias psicoanalíticas que el protagonista debe destruir. Finalmente, Silent Hill: Shattered Memories es estudiado como un juego que, incluso más que otros, pone en primer plano las referencias explícitas de la serie a cuestiones psicoanalíticas, entroncando con las interpretaciones contemporáneas acerca de la relación entre la memoria, los medios y la fantasía.

PALABRAs Clave: Silent Hill, horror, psicoanálisis, videojuegos, memoria.

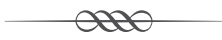

\section{INTRODUCTION}

This paper continues an established scholarly tradition, identified by E. Ann Kaplan, in its application of psychoanalysis «as a tool for analysing literature and anthropological texts» (1990: 12). Psychoanalysis provides a compelling framework for exploring the medium, as evidenced by Rebecca $R$. Tews' (2001) Jungian consideration of videogames, Bob Rehak's (2003) Lacanian, and Diane Carr's (2006) Freudian-informed reading of the player-avatar relationship. Marc C. Santos and Sarah E. White's (2005) use both psychoanalytic branches in analysing processes of videogame play, and, as the focus of these latter studies suggest, it is the horror videogame which appears most suited to such a theoretical approach. The genre's remediation of horror aesthetics, codes and conventions; its combination of grotesque imagery, tormented protagonists and body horror; its representations of monstrousness, the abject, and the uncanny, prove resonant with psychoanalytic themes and preoccupations. Such a project is not unproblematic. Suggesting a perversity to videogames and the desires they mobilise risks a pathologisation of the 
videogame player, an early concern of psychoanalysis in film theory (Buscombe et al, 1992: 42-43). As Carr (2002) asserts, amongst others aspects of the medium, relationships between player and avatar differ significantly from those between cinema spectator and film star, complicating any straightforward application of film psychoanalysis to the videogame. In keeping with the emphasis within game scholarship on attending to the "gameness» of its object of analysis, the aspects which make videogames distinct from other art forms, this paper will maintain a focus on the manner in which its case study presents a medium-specific mobilisation of and reflection upon psychoanalytic themes, such as the uncanny, the primal scene, and the complex interconnection between memory and fantasy.

The intentions of this paper are to illustrate the ways in which psychoanalysis, as an approach to analysing media texts and apparatus, affords greater appreciation of the discomforting effect of horror videogames, specifically within the Silent Hill series. This long-running franchise has produced eight major titles to date following from the first instalment's release in 1999. It is widely understood as belonging to the "survival horror» videogame subgenre, a critically recognised cycle in which «the player controls a character who has to get out of some enclosed space solving puzzles and destroying horrific monsters along the way» (Egenfeldt-Nielsen et al, 2008: 184). In contrast to other film, television and videogame franchises, and other examples of survival horror, the Silent Hill series is characterised by a significant lack of coherence. Each game has a different protagonist, with only a few recurring characters featuring in often-peripheral roles. The narratives of each title are necessarily divergent, being organised around the past lives and experiences of various protagonists, and although the series has a recurring story relating to a cult of Silent Hill, a magical child nearly burned to death by her mother, and the consequences of her subsequent incarceration in a local hospital, these events, like the characters within them, often have only a tangential relationship to those of individual games. The main consistent element across the series is the town of Silent Hill, although this is an ambiguous location, subject to transformations, mutations, breakdown in the laws of spatial logic, with some games taking place in surrounding areas rather than within the town itself. The canon of the series is complicated by inconsistencies in the organisation of space, places and timelines, and in the presence of multiple endings to all games, providing different interpretations of events, conclusions to core narratives, and connections with subsequent titles. Of the many endings to the first game in the series, only one proves consistent with the third instal- 
ment, while the seventh game follows on from a quite different conclusion and proposes a radically different meaning to events across the franchise. The very title of the forthcoming release, Silent Hills, currently available only as a playable demo, reflects the fragmentation and multiplicity of the series itself.

This is a game explicitly themed around issues of trauma, psychological breakdown, repressed memories, perversion and familial dysfunction. The uncanny monsters, womb-like spaces, devouring mothers, and dreamlike cut-scenes of the Silent Hill games, effectively designed to unsettle, disgust and traumatise its players, suggests a series which can be productively examined through reference to principles of Freudian psychoanalysis. The series is filled with characters suffering from amnesia relating to some unsettling childhood experience or crime they have committed. James Sunderland of Silent Hill 2 murdered his wife; Alex of Silent Hill: Homecoming killed his brother; the mother of Travis, hero of Silent Hill: Origins, tried to kill him, after which he found his father hanged in a motel room. There are suggestions that the town of Silent Hill represents a beacon to particularly troubled individuals, for whom the landscape and the creatures within it assume a reflection of their own inner turmoil. The ways in which these repressed elements manifest as monsters in climactic boss battles suggests a therapeutic process whereby distressing memories take physical form, are confronted, and destroyed. The player participates in such processes, battling these inner demons on the protagonist's behalf, vanquishing these manifestations of their guilt, trauma, and personal conflict.

A detailed focus on the Silent Hill series distinguishes this paper from the previous work on psychoanalysis and videogames referenced above. Tew's (2001) chapter is a broad examination of games of different genres and periods, including Pac Man, Diddy Kong Racing and Tomb Raider. A recurring concern of this author relates to the social impact of the new medium, an issue of no concern to this paper, employing a modern psychology perspective which includes behaviourism and social learning theory, alongside Freudian and Jungian psychoanalysis. The author's application of Jungian archetype theory, proposing videogames' continuity with myths, fables and legends in speaking to a primitive collective universal humanity, is compelling but necessarily undeveloped and unfocussed. Rehak (2003) is largely concerned with the application of Lacanian psychoanalysis to the «unstable dialectic» between the player and avatar, a figure which is both self and other, ideal and inferior, object and subject, splitting and suturing. This is illustrated in what the author acknowledges is a similarly limited historical account, emphasis- 
ing the increasingly sophisticated sense of mimicry, corporeal embodiment and «subjectivization» in videogame's development. In its emphasis on demystifying the videogame's interpolating apparatus, rather than deconstructing specific textual experiences, Rehak does not focus on any particular game, genre, or series. This chapter connects with Carr's (2006) comparative study of Silent Hill and Planescape Torment which also interrogates the avatar of the horror videogame, as an uncanny, rather than reassuring, double, carrying with it qualities of the 'harbinger of death' Freud attributed to the doppleganger. While this paper shares Carr's title of study, extended across the series' subsequent instalments, the notion of the uncanny in this paper is applied to adversaries and game spaces, rather than the figure the player controls. The study of Resident Evil and Silent Hill presented by Santos and White's (2005) contains a discussion of the Oedipal forces at work within the games which parallels this paper's analysis of game spaces. The player is here described as the «defender of subjectivity», a role enacted primarily through destroying figures representing an abject Other, and piecing together the fragmented game elements into a coherent story. Such a function, this paper would argue, is largely frustrated by the persistent incoherence of the Silent Hill game series, exacerbated with every new release, which offers players little hermeneutic pleasure of narrative mysteries resolved. Of particular relevance to this paper is Santos and White's suggestion concerning the position of player as analyst to the analysand protagonist, in a series which appears explicitly informed by the influences of psychoanalysis. The impact of Freudian preoccupations on game design is evident across the series: in the Oedipal killer of Silent Hill 4 and the umbilical cord object which is central to the game's climactic scene; in the presence of the Jocasta Artefact in Silent Hill Origins which allows the hero access to the mother's cell; and in the structure of Silent Hill: Shattered Memories, organised around a discussion between an unseen character and a psychotherapist. The Making of Silent Hill 2 documentary, released along with the game itself, makes repeated reference to the «psychological horror» of the game, foregrounding the designers' intention to depict "what's deep within the mind», and the principles of attraction and repulsion which informed the game locations; while in a section titled «Eros and Thanatos» a visual designer tells of the deep human preoccupations of sex and death which were mobilised in the production of the title. Consistent with Santos and White claims, the presence of such paratextual material suggests that the implied player of this game is one primed to use psychoanalysis as part of their interpretive framework in appreciating the game experience. 
The aim of this paper is to illustrate how psychoanalytic frameworks facilitate an understanding of the medium-specific ways these games generate a sense of unease and disquiet; how grammatical structures and conventions common across the videogame medium are twisted to serve the expression of narratives in which protagonists battle psychological demons from their past; and how the interactivity of the medium affords an interactive expression of the malleability of that past and the degree to which personal memories are as much a construction of an individuals' present psychology as actual events. Inherent in such a project is an engagement with the productive potential of applying psychoanalytic approaches beyond this case study, thrown into relief by their explicit mobilisation across this particular series. The monsters in Silent Hill 2 which scuttle across the ground in the manner of clockwork contraptions, capitalise upon the already-uncanny aspects of non-playable characters in videogames, figures imbued with a strange artificial liveness which derives from the computation of a non-organic games console. The design of boss battles to symbolise traumatic experiences from the game protagonists' past suggests the potentially psychic processes mobilised by this trope of videogame play; while the introduction of these monsters of the id into the game space through non-interactive cinematics implies their unconscious origins through association with the medium of cinema. In contrast with the spatial and narrative consistency of traditional videogames, and traditional media, Silent Hill presents players with architecturally-impossible locations where the same door does not necessarily lead from the same room; levels which alternate disorientatingly between playable and non-playable sequences, or constitute an unexplained amalgamation of previously encountered objects and settings; or spaces and stories which deviate wildly dependent on the input of the player. As such the series illustrates the potential of the videogame medium to represent the irrational, the inconsistent, the unfixed, the fantastical in a manner distinct from other forms of visual culture.

The uncanny nature of Silent Hill spaces will first be explored, drawing on work paralleling videogame environments and the maternal womb. This is a quality enhanced within the series, through the design of game spaces as dark, bloody, abject environments, accompanied by parallel narratives which feature protagonists investigating their past and parental origins. The relationship between playable and non-playable cut-scene sequences is then examined, according to a framework corresponding such distinct aspects with the conscious and unconscious dimensions of the psyche according to Freudian psychoanalysis, the latter reproducing qualities of the primal scene in pro- 
viding flashbacks and narrative context to gameplay. The final section of this paper focusses on Silent Hill: Shattered Memories and its reflection upon processes of remembering, the impact of media such as family photographs and home movies on these processes, and the ways in which memory entails as much a fantasy as authentic reflection of the subject's life history.

\section{Gamespace as Maternal Womb}

The videogame medium is haunted by a sense of the uncanny. As a representational medium, videogames are not unique in this respect. Waxworks, photography, cinema, and broadcast media have all been considered imbued with unsettling qualities as they disturb the boundary between animate and inanimate, between life and the lifelike, between the human and non-human (Sconce, 2005; Warner, 2006). Videogames, with their promise of immersing players in complex, responsive, interactive, realistic environments, in videogames' simulation (Frasca, 2003) rather than simple representation of real life, have the potential to produce an even more extensive uncanny experience. The dense responsive urban ecology of cities in the Grand Theft Auto series. The increasing photorealism of the female protagonist of Tomb Raider. The repetitive mechanical movements of adversaries in Nintendo's Mario games. The strange relationship between player and avatar, as an inanimate digital puppet becomes imbued with life and, in a cybernetic exchange with the game apparatus, the player becomes increasingly machine life in their identification with the world of the computer or console. These might all be understood as expressing qualities of the uncanny. However, while this concept has significance for the videogame medium as a whole, evidenced by the notion of the «uncanny valley» across digital media, as Richard J. Hand (2004: 117 ) identifies, it is a quality deliberately capitalised upon within the «sustained uncanny environment» of the survival horror genre. The world of Silent Hill, both the town and the game series, reflects many aspects of Freud's (1990) definition of this ambivalent term. These games are full of haunting doubles, dream-like sequences, and monsters which unsettle the boundary between animate and inanimate. Manikins, puppets, walking furniture and clockwork creatures are amongst the many creatures which players encounter while navigating the disturbing spaces of the series, capitalising on the already-unsettling qualities of the not-quite lifelike non-playable character. The environment of Silent Hill initially embodies the familiar world of an all-American small town, site of white picket dwellings, burger bars, convenience 
stores, motels, gas stations, fire hydrants and vending machines. But, a defining feature of the series, periodically this space is transformed into the Otherworld, a doppelganger which retains the same architectural structure of the former Silent Hill, but is characterised by decay, dereliction, darkness and dirt, the previous banality of which, Carr argues, makes their nastiness all the more disturbing (2006: 65). The eagerly anticipated moment in Silent Hill: Homecoming (2008) when the family home peels away to reveal the rusty metal walls, stained tiles and blood-red surfaces of this nightmare shadow world perfectly expresses and illustrates the central paradox of the uncanny, representing both the homely («belonging to the house») and the unhomely («obscure», «hidden and dangerous», «secret»). Indeed, the central premise of this instalment resonates with an uncanny encounter, revolving around a protagonist returning to his home town, only to find it strangely unfamiliar.

Although Espen Aarseth proclaimed 2001 «year zero» in videogame scholarship, a number of publications exist prior to this date, considering videogames from a range of perspectives. One such contribution is Gillian Skirrow's 1986 chapter 'Hellivision: an analysis of video games' which argues that game spaces and experiences can be understood as investigations of the maternal womb. Here Skirrow asserts: «Video games... are about mastering a specifically male anxiety in a specifically male way» (1986: 138); and, despite the negativity which characterises this assessment, with its broad denial of female gamers, the author's observations have productive application to Silent Hill. Drawing upon Melanie Klein's analysis of children's play, Skirrow argues that for male players, videogame spaces represent the mother's body's interior, a source of both fascination and fear reflecting the ambivalent attraction and repulsion of the Freudian uncanny. According to Skirrow, videogames' appeal to young males resides in the medium's construction of gamespace, be it catacomb, tomb or spaceship, as «maternal cave». This analysis, written in the early years of home computers and consoles, is unfortunately non-specific when it comes to game titles, and does not identify such qualities as specific to any particular genre. But these aspects are profoundly, even explicitly, evident across the Silent Hill games. These are full of bloodied spaces and twisting passageways, accompanied by imagery of birth and death, and by narratives entailing the interrogation of a protagonist's own origins. Silent Hill 3 (2003) is organised around Heather's journey of self-discovery, and involves a level set in a hospital where the player navigates strange red corridors which pulse as though alive. Underlining such visual signifiers of birth and maternity, the game culminated in a church where the protagonist orally 
ejects her own unborn foetus before leaping into a bloody vaginal hole for the game's final confrontation. The family home of Homecoming is aligned with the protagonist's mother, through her near-catatonic presence in the living room, the domestic spaces the player explores, and in an attic-set puzzle which involves placing masks on corpses representing the emotionally distant maternal parent. The franchise's most explicit womb-space is the titular room of Silent Hill 4 (2004). Previously inhabited by the mother of a serial killer, this explicitly uterus-coded apartment represents the imagined site of the antagonist's birth and/or conception, which in the murderer's mind comes to represent his mother's body. Reflecting the womb space's ambivalent status, the game's second half sees this apartment, previously a restorative sanctuary, transformed by bloody health-sapping apparitions, which can be exorcised only through erecting phallic candles.

Silent Hill's use of sinister womb-like spaces, monstrous mothers, and the threat of maternal engulfment has a tradition within the horror genre. As Barbara Creed writes, «a reconciliation with the maternal body, the body of our origins, is only possible through an encounter with horror, the abject of our culture» (1993: 41). Although Creed's discussion of the monstrous mother is largely restricted to Western cinema, Ruth Goldberg identifies the bukimi-na baba-mono or «Uncanny Mother» film as reflecting similar ambivalences surrounding the mother figure in Japanese society. A nightmarish entity, with connections to insanity and the supernatural, Goldberg traces this trope from the recent Ringu (1998) and Dark Water (2001) to the 1926 film A Page of Madness. In a narrative remarkable similar to the sanatorium level of Origins, a game in which protagonist Travis unravels the story of his mother's mental breakdown, Goldberg tells of «the Uncanny mother, once familiar, now unfamiliar, who abandoned her family after trying to drown her infant son years earlier, and who has retreated into a world that no one else can access» (2004: 372). In Origins Travis unwittingly follows in the footsteps of his infant self, breaking into the asylum where his mother was incarcerated following her attempt to kill him. Evident of the videogame's implication of the uncanny mother in game spaces and architecture, along the way Travis discovers ghostly traces of her presence, in graffiti, hospital records and audio recordings, before entering her cell, heralding a dramatic boss battle with a grotesque version of the woman. Skirrow's (1986) concept of the gamespace as implicitly connected with the maternal womb becomes explicit in this and other Silent Hill instalments, enhanced through the generically-specific design of game architecture, objects, narrative, and boss battles. 
Travis's mother is not the most significant monstrous mother within the Silent Hill series. The franchise's convoluted narrative revolves around Alessa, a magical young girl, destined to birth the god of the Cult of Silent Hill, only to rebel against the order. For this her mother tries to burn her to death in the family home. Alessa's blackened bandaged body is subsequently incarcerated in a local hospital where she remains in a comatose state of neardeath. An archaic mother, defined by Creed as «the mother who conceives all by herself, the original parent, the godhead of all fertility and the origin of procreation» (1993: 27), in order to escape, Alessa splits in two, producing an infant version of herself which is adopted by a childless couple. Several years later this child, in the form of Cheryl, returns to Silent Hill with her father, whereupon the events of the first game begin. The primeval mother's formless-yet-totalising omnipresence is expressed through Alessa's implication in the periodic transformation of game spaces into the dark womb-like Otherworld. Alessa's cannibalistic aspects, consistent with the archaic mother figure, include the monstrous creatures these levels contain which threaten to consume the protagonist, as well as Alessa's intention to reabsorb her own magical daughter thereby making herself complete. Alessa's status as self-generating archaic figure, similar to the double mother monster Santos and White see in Resident Evil's Alexia Ashford (2005: 72-73), is graphically realised when Heather encounters a religious painting depicting Alessa as both Madonna-like mother and Christ-like child, the significance of which is enhanced through the presence of an enormous resurrecting save point on the floor. This painting reproduces what Fletcher observes in the Gothic heroine narrative as the «uncanny and doubling relation between the youthful protagonist and the older woman» (1995: 346). Like many Silent Hill characters, Heather is haunted by Alessa, but for the only female hero of the franchise, this fractured figure represents at the same time rival, doppelganger and mother. Heather states her discomfort around reflections, and is attacked by a series of increasingly bloody versions of herself in a merry-go-round battle. The third instalment reproduces key scenes from the first game, uncannily rendered in the enhanced definition of the next generation console. A further doubling constitutes the moment where Heather is revealed to be Cheryl, Harry's daughter, the figure players pursued across town in the first game of the series, reincarnated again as an infant following the episode's conclusion, as well as being another version of Alessa herself. As the non-playable character becomes playable avatar, we see uncanny tropes of horror culture transformed according to the structures and affordances of the videogame medium. 


\section{Primal Cut-Scenes}

A standard structure within particularly narrative-based videogames is for the experience to oscillate between audio-visual sequences which are simply viewed by the player, and more extensive periods of gameplay where the user enjoys varying degrees of control over events unfolding on screen. Such 'cinematic' moments remove control from the player, placing them in the physically-passive position of the film spectator, and variously function to communicate the narrative of the game, to provide contextual information concerning the completion of tasks, and to allow a dramatic pause before the start of a major confrontation. Technically, cut scenes constitute elaborate loading screens intended to keep players distracted while various computations run behind the scenes, signalling a significant shift in the gamespace or mode of gameplay, and the advent of particularly challenging set piece sequences of interaction. A crude psychoanalytic model might be applied to the dichotomy between playable and non-playable moments, related to the conscious and unconscious, or the ego and the id. Playable sections exist under the player's rational control, are organised around the coherent subject of the avatar, and unfold in unified space and time. Conversely, cut-scenes appear suddenly, are filled with uncontrollable images, edits and camera angles, and reproduce continuity cinema's disembodied dream-like omniscience. This structure is common across genres, from racing games to platform games to action adventure titles. Indeed, according to the grammar of the videogame it would be rare indeed for a significant confrontation or boss battle, be it in a Mario game, a science fiction adventure, or a button mashing arcade game, to begin without such a transition. Even mobile phone puzzle games with barely any narrative content often feature brief animated sequences to mark the transition from one set of puzzles to the next. However, as with the uncanniness of the womb-like game space, the psychoanalytic aspects of the experience are given a resonance, and even explicit emphasis, within the horror genre and within the Silent Hill series in particular.

One of the earliest analyses of horror videogaming is Tanya Krzywinska's (2002) «Hands on Horror». Here the author argues that the impact of horror videogames hinges on the oscillation between control and its withdrawal, an infrastructure Krzywinska relates to a 'moral occult', the organisation of emotional suspense and tension, and a sense within horror videogames of the supernatural as having an irrational and uncontrollable influence on the player. This dichotomy between agency and its denial, between doing 
and not doing, determination and non-determination, agency and helplessness, which Krzywinsha considers so central to the genre, is exemplified by the distinction between playable sequences and the cut-scene. In Silent Hill the sense of cut-scenes as representing both loss of control and psychological rupture is particularly evident in their use to signalling shifts from the normal world to the abject Otherworld. As Carr (2002) argues, the interactivity of videogames constitutes but one aspect that renders film psychoanalysis inappropriate in analysing the medium, and yet such aspects of cinema may be thrown into relief and even explicitly mobilised in their contextual location within interactive experiences. The transition cut-scene shift from normality to Otherworld is frequently a visually arresting dramatic sequence, where surfaces peel and crumble into darkness, blood seeps through pipes, walls and ceilings corrode with rust, as the protagonist stares in helpless horror and disbelief in a manner similar to the implied player. The fantastical imagery of these cinematic sequences, and others across Silent Hill, evoke the psychoanalytic dimensions of cinema, considered by many early theorists as a medium inducing hypnotic, dream-like sensations. Jean-Louis Baudry (1986) compares the mechanisms of Plato's cave, the sleeping state, and cinema spectatorship, arguing the cinematic apparatus reproduces various archaic experiences associated with early stages of infancy. The tension between control and its removal, between the interaction of the videogame and the non-interactive cinema, between gameplay and the cut scene, in evoking a dream-like sense of the supernatural and the unconscious determining the player and protagonists' actions is realised in the opening sequence of the series. The original game begins with a brief scene showing Harry Mason emerging from his crashed car, seeing his daughter Cheryl run into the mist, and following her into a dead end alleyway. In the process of steering the avatar to this point, gameplay is periodically interrupted as Harry spots his adopted daughter in the misty distance. These sequences function to associate gameplay with the character's desire to find Cheryl, while the frustrating interruption represented by these brief non-participatory moments exemplifies the generic determinism Krzywinska discusses, as Harry is led to his inevitable death. The surreal dream-like sensation this sequence evokes is consistent with the moment Harry wakes to find he has inexplicably fallen asleep in a Silent Hill diner, and everything up until that point has been a dream. If cinema's psychic hold is maintained through physical passivity, immobility and powerlessness, the horror games' cinematic cut-scenes' syntagmatic location within sequences of interaction enhances these qualities. Within Silent Hill the intru- 
sion of such moments, in conjunction with other generically-specific aspects of the series, contributes to the unsettling possibility that gameplay constitutes an extended dream or psychotic episode experienced within the protagonist's head.

One clear function cut-scenes commonly serve is to locate gameplay within a narrative context. Traditionally an extended cut-scenes features at the beginning of a game. Silent Hill 2 opens with a series of monologues from the protagonist concerning his search for his wife; Silent Hill 3 begins with Heather finding herself at the gates of a terrifying theme park with only a knife for protection; Homecoming starts with Alex Shepherd arriving in his deserted home town. Film theorist Elizabeth Cowie's discussion of cinema and Freudian fantasy has further applications for videogame cut-scenes' narrative function. The author's description of fantasy as «an imagined scene in which the subject is a protagonist, and which always represents the fulfilment of a wish» (1997: 127) incorporates the videogame experience, including avatar («subject» as «protagonist»), game goals («fulfilment of a wish»), cutscenes and game spaces (the «imagined scene»). The «imagined scene» Cowie discusses according to Freud's "original fantasies», revolves around major enigmas concerning a child's existence. Cut-scenes' similarly function to explain, contextualise and locate play in the form of backstory, establishing scenarios for particular set pieces, providing hints concerning obstacles or puzzles. This is the function of cut-scenes across game genres, but in Silent Hill, where narratives frequently concern the protagonist searches for clues to their past or parenthood, the resonance of cut-scenes with primal scenes is even more apparent. In Homecoming many cinematics encountered while investigating the family home relate to the protagonist's troubled relationship with his father, ultimately leading to the revelation that Alex accidentally killed his brother as a child. As with many games in the series, the narrative communicated through cut-scenes relates to the troubled history of the protagonist and the narrative situation in which they find themselves. In the appropriately-titled Silent Hill: Origins, having traced his way through the sanatorium level, and used the significantly-titled Jocasta Artefact to gain access to the female seclusion unit, a cut-scene shows the young Travis confronting his mother, a moment which segues into the game's first boss battle. Without this, the distorted monster the player fights would have considerably less narrative significance, or Oedipal resonance.

Cut-scenes also function to herald boss battles. Like the Otherworld transition sequences, these burst onto the screen, dramatically interrupting 
gameplay, depicting monstrous eruptions, animations, resurrections and births. Again, such components are not specific to Silent Hill, but the sense that these moments constitute intrusions of the unconscious mind into the rational world is enhanced by the extent to which these creatures, either Heather's doppleganger self, James' dead wife, or Travis' parents, represent some significant point of psychological conflict or repressed memory for the protagonist. Once these cinematics have run their course, control returns to the player who, in a dynamic analogous to the neurotic battling their inner demons, must deal with the creature now invading playable space. Like a recurring nightmare, unless the player succeeds on their first attempt, these sequences must be repeated until the monsters they produce are vanquished. In this respect videogame play evokes Freud's discussion of «the compulsion to repeat» (1991). Observing how dreams of traumatised patients return sleepers to the experiences which produced their neurosis, Freud hypothesised that sufferers unconsciously seek to develop psychic coping strategies by enacting and re-enacting forgotten or repressed causal points in their breakdown. Significantly, in the same essay Freud discusses the fort-da game played by a small child, an aspect of psychoanalytic theory Rehak also applies to digital games (2003: 110). In staging the disappearance and return of his mother using a cotton reel, the author argued an infant was attempting to achieve control, empowerment and agency over an original experience of powerlessness and passivity. Again, the narrative and design of Silent Hill seems deliberately designed to evoke such analogies. Like the dreams of trauma sufferers, cut-scenes ready players for battle; like the playing child, the videogame players' ultimate goal is control of a chaotic situation; and like the cotton reel, in Travis' case the monster symbolises the mother's body which must be subjected to sadistic mastery. Upon succeeding, the maternal boss's defeat is represented once more through cut-scenes. In such ambiguous moments of victory, control and agency are once more wrenched from the player's hands as the screen becomes «bordered with black like a letter of condolence», a remediated signifier Baudry associates not only with the spectator "chained, captured, or captivated» by the film image, but also with suggestions of death (1999: 352). In a manner characterising the death instinct, the urge to return to an earlier state of lifelessness and inanimation which Freud develops alongside the compulsion to repeat, players anticipate this relinquishing of control. The black borders indicating player success even as their participatory presence is removed and they are positioned as a still, inactive, non-player. 


\section{Memory, Media, And Silent Hill}

Silent Hill is a town populated with traumatised protagonists struggling to deal with repressed memories, often externalised in the form of monsters and boss creatures which must be battled in order to complete the game. James appears to have forgotten that he was responsible for his wife's death, his guilt at what he has done symbolised by a grotesque creature he eventually confronts on the roof of their honeymoon hotel. Cheryl has repressed knowledge of her unpleasant childhood as the abject Alessa, expressed in the doppleganger which haunts her throughout the game, and the series of bloodied versions of herself which she fights in a dramatic fairground set piece. Travis retraces the path of his own childhood, through the hospital where his mother was incarcerated, to the motel where his father killed himself, both parent figures appearing as bizarre monsters which must be defeated. The landscape of Silent Hill is as much a reflection of the internal world of these protagonists as it is an external reality, the final level of the original title being an inexplicable amalgamation of locations encountered throughout the game, like a surreal dream-like jumble of memories of places and objects. The centrality of memory to the series is reflected in the title of the obscure Silent Hill: Book of Memories. The bloodied copies of her own avatar which Heather battles are titled «Memory of Alessa»; Alex collects «memories» throughout the hotel level of Homecoming as part of a puzzle task; while Harry collects bonus «momentous» scattered across the snowbound town in Silent Hill: Shattered Memories. As the title suggests, this instalment takes memory as its central concern, and might be considered the franchise's most explicit engagement with psychoanalytic preoccupations, being structured as a series of narratives related to a psychotherapist. The final section of this paper will concern itself specifically with this instalment of the Silent Hill series, and the ways in which its depiction of processes of memory can be understood in relation to the emerging interdisciplinary field of memory studies. While other medium-specific aspects considered above, such as the uncanny nature of non-playable characters and spaces, or the function of cut-scenes as primal scenes, have potential applicability across other videogame titles and genres, these aspects of the Silent Hill series and of this game in particular are unique to the franchise.

Shattered Memories opens with a scene resembling a home movie, depicting a young Cheryl, the runaway daughter from the first game, and her father Harry at an amusement park, a fantastical setting in which they are filmed as damsel in distress and knight in shining armour. The sequence con- 
cludes with Cheryl expressing love for her father, a sentiment rewound and replayed with obsessive compulsion as the opening credits roll. From the outset, the game introduces a central theme, one present in previous instalments, being the close relationship between media and memory. The role of media in the archiving, circulation and construction of both individual and collective remembering has been identified by many scholars within the field of memory studies. Joanne Garde-Hansen (2011) writes of the symbiotic relationship between media and history, our engagement with the past being mediated and mediatised through print, film, photography and digital media. Freud himself, in discussing memory, uses two media metaphors: the magic writing pad and the screen. The latter, Alison Landsberg argues, indicates an understanding of the role of mass media on processes of memory (2004: 15-16); something reflected in the opening assertion of Russell J. A. Kilbourn's examination of memory in transnational and art film, that «cinema - alongside photography - is constitutive of memory in its deepest and most meaningful sense» (2010: 1). Opening the game in this way suggests an awareness of the significant role of domestic media archives in quantifying an engagement with family history and personal past, and the dysfuntionality that such a relationship may produce.

Nichola King, in Memory, Narrative, Identity: Remembering the Self, writes of a tension in Freudian psychoanalysis between memory as a buried preserved structure in need of excavation but existing in a fixed sense, and memory as a process of revision and rewriting in the light of subsequent experience (2000: 4). Across the Silent Hill series, protagonists uncover a past evidenced by its material embodiment in historical texts, suggesting the former conception of memory. Analogue media within the games, such as print, photography, audio recordings and paintings, frequently represent a source of authenticity, enhanced by their virtual context, suggesting an embodiment in the indexical relationship between subject and light sensitive paper, or the voice and magnetic tape. These diegetic texts are static and non-participatory, functioning in a similar manner as cinematic cut-scenes, interrupting the flow of real-time play so that the player can absorb the narrative information they contain. In Origins the sense of a cinematic intrusion, with all the authority the analogue medium implies, is constructed through the adoption of a scratchy monochrome filter over the game world whenever Travis listens to tape recordings. This shift in aesthetic reflects Paul Grainge's (2002) discussion of black and white as a signifier of "pastness», in historical films, photo journalism, and nostalgic advertising. At the same time the technique mobilises a less 
reassuring sense of the corroded monochrome aesthetic as representing the arcane, appropriate within a horror context where the past is a disturbing force rather than a resource of comfort and security (Kirkland, 2009).

The relationship between media and memory is not without contention, and many academics assert that media, far from unproblematically reflecting the past, actively constructs it in a manner which throws into question the very processes of remembering. Amongst the work of authors exploring the interconnection of media and memory, Garde-Hansen observes «a gathering storm around potential inauthentic and commodified uses of memory» (2011: 27). Landsberg (2004) coins the term "prosthetic memories», contrasted with «natural» or «authentic» memory, in an exploration of ways in which modernity and mass culture have transformed society's relationship with its past, heralding new forms of public cultural memory. Celia Lury (1998) also asserts the «prosthetic» nature of memory in relation to photography and broader notions of identity. As Marianne Hirsch writes of family photographs, like the portraits of Alex missing from his family home, and the path of photos he follows throughout Homecoming: "Our memory is never fully "ours," nor are the pictures ever unmediated representations of our past. Looking at them we both construct a fantastic past and set out on a detective trail to find other versions of a "real" one» (2002:14). The potentially treacherous ways in which mass and domestically-produced imagery constitute our collective and individual sense of the past, and the extent to which memory itself may depend as much upon the individual's current state as actual events, is reflected in Shattered Memories, a game with a considerably different structure to earlier instalments. In contrast to the status of media as a source of authenticity which can be excavated by the player protagonist, this game mobilises the second sense King (2000) identifies, of memory as a process of revision and rewriting. Ostensibly a remake of the first title in the series, the game opens in a psychiatrist's office where the player, as an unseen first-person protagonist, answers a series of questions to a malcontent doctor. The patient then narrates the traumatic events of Harry searching for his daughter Cheryl, which unfold as an interactive third-person flashback. Throughout his journey, Harry encounters various characters whose reactions suggest he is, as a typical visitor to Silent Hill, suffering from amnesia, having forgotten his relationship with the town, its people, even the age of his own daughter. More significant, the events the protagonist narrates are not simply subject to the interactive control of the player; the design of spaces, cut-scenes and non-playable characters are determined by players' responses to the psychiatrist's tests. The protagonist's memories, 
narrated to the increasingly sardonic councillor, therefore appear inflected by their current personality and psychological state as chosen by the player. Responding differently to the questions produces a different game and, by implication, a different version of the remembered past. In contrast to the static media of previous instalments, memories appear as an interactive experience which can be potentially transformed by repeated plays.

A central device in Shattered Memories is a multi-media smart phone, which the player uses to access ghostly voice messages and photograph spirits, depicting tragic events which have imprinted upon the present. Anachronistic, given the game's apparent location in the events of the first episode, released in 1999 well before the commercial availability of multimedia mobile phones, the smart phone's presence constitutes an indication that this is not an entirely accurate or truthful representation of the past. Moreover, for a player of the first game this instalment will differ significantly from their memory of the original Silent Hill, further questioning the authenticity of events within the admittedly confusing and contradictory canon of the series. These issues come to a head in the game's conclusion, where it is revealed that the unseen narrator in the doctor's office is not Harry Mason, but his daughter Cheryl. These are not memories, as implied by the game's title, but a fantasy concocted by a young woman traumatised by her father's departure from the family home, and subsequent death. If, as Santos and White observe, in Silent Hill «we are never sure whether the games' diegetic worlds are manifestations of psychotic minds or the results of supernatural forces» (2005: 75), Shattered Memories comes down clearly on the side of the former. Photographs the player takes with Harry's phone actually represent Cheryl's memories of being sexually humiliated at school. The mementoes are Harry's daughter's cherished possessions. The camcorder fragment, which features as ghostly images in the game world itself, is one she has fetishized in her construction of an ideal relationship with an imaginary father figure. The psychiatrist's unsympathetic attack on Cheryl, implicit in his angry description of the creatures who populate her nightmare world as «blind children clutching photos in the dark» and "pale freaks goggle-eyed from watching home movies on loop», echo the degree to which Lury observes mechanical reproduction has been repeatedly implicated in maladies such as multiple personality and false memory syndrome, observing «a parallel or analogy drawn between recovered memories and photographs or video-recorded images» in practically all the accounts she surveyed (1998: 122-123).

At the same time as home movies are instrumental in the fictional fa- 
ther Cheryl has invented, in the game's final moments the camcorder becomes witness to the truth. Depending on the player's performance within the game, various endings are screened, each of which concludes with video footage featuring Harry supposedly exposing his true self: as a drunk, as an adulterer, as a pathetic figure bullied by his wife, or as a devoted father expressing love for his daughter even as he leaves home forever. Despite the implications of the home movie as a disseminator of family fictions and false memories, in the final moments the game betrays a persisting «analogue envy» across the series, wherein non-digital media function as authentic representations of past events and, admittedly uncomfortable, truths. Consequently the shattered memories of the protagonist are made whole again in a more traditional form of narrative or game closure.

\section{Conclusion}

The intentions of this paper are relatively modest. At this early stage in the history of the videogame medium, and its discussion within academic circles, this contribution is intended to enhance the growing body of multidisciplinary approaches to videogame analysis, as well as the appreciation of distinct qualities relating to this emerging art form. Throughout this paper a focus has been maintained on the ways in which the videogames as a culture different from literature, film, television, and other visual arts, engages with psychoanalytic preoccupations. The uncanniness of artificial intelligence and digitally-generated images exists in a different order to that of the waxwork or the photograph. Videogames offer a unique combination of spatial investigation and narrative exposition, affording a potentially compelling engagement with Oedipal structures which is unlike other storytelling forms. The oscillation between interaction and its withdrawal, realised in a medium which offers the user a physically active role in the construction of the audiovisual experience, might reflect upon relationships between conscious and unconscious psychic components in a manner non-participatory media cannot afford. The transformation of narrative and space according to player input allows game systems to reflect upon the fragmented, multiple, contradictory nature of the psyche, the ways in which mental states impact on perception, and the problematic relationship between an individual and their personal history, not possible in more static texts. While references to other game titles has served to contextualise common qualities of the medium, the focus of this 
study has been on a series which is far from typical in its content or structure. This necessarily limits the applicability of its conclusions across the range of experiences covered by the term «videogame». Claims concerning the design of game spaces as maternal womb are undoubtedly enhanced by the dark and bloodied design of Silent Hill's Otherworld, and by narratives entailing an investigation of the protagonist's forgotten past. A distinction between unconscious cut-scenes and conscious playable sequences are made more meaningful in the context of boss battles where the monster represents a physical manifestation of the hero's troubled past. When it comes to the depiction of memory in the franchise's seventh title, this involves a function quite unique to the series. Finally, while using psychoanalysis as a theoretical framework, it is not the intention of this paper to pathologise the player of such games. Santos and White's (2005) argument that the Silent Hill series effectively positions the player outside the psychological zone of the videogame, constructing a relationship analogous to that between psychiatrist and patient, whereby the gamer observes the game space as a reflection of the protagonist's damaged psyche, seems like a healthy one. It is a position invited by the explicit references to Oedipal structures in game objects, by narratives concerned with family dysfunction, monstrous mothers, and psychological trauma, and by the recent instalment which literally places the protagonist on the couch. This model of the game player presents a valuable counter-argument to prominent discourses of videogame immersion and absorption, the basis of many claims concerning the damaging effects of videogames on players, and a simplification at odds with the tensions between attraction and repulsion of the horror videogame. As a mature series the Silent Hill games do, at many points, revel in their depiction of the perverse, the grotesque, the disturbing; but these not so much sick games as they are games about sickness.

\section{BIBLIOGRAPHY}

BAUDRY, Jean-Louis (1999): «Ideological effects of the basic cinematographic apparatus», in Leo Braudy and Marshall Cohen (eds.), Film Theory and Criticism: Introductory Readings, Oxford University Press, Oxford, pp. 345-355. <http:/ /dx.doi.org/10.1525/fq.1974.28.2.04a00080z>

BAUDRY, Jean-Louis (1986): «The apparatus: metapsychological approaches to the impression of reality in the cinema», in Philip Rosen (ed.), Narrative, Apparatus, Ideology: A Film Theory Reader, Columbia University Press, New York, pp. 299-318.

Buscombe, Edward, Christine Gledhill, Alan Lovell and Christopher Williams (1992): 
«Psychoanalysis and Film», in The Sexual Subject: A Screen Reader in Sexuality, Routledge, London, pp. 35-46.

CARr, Diane (2006): «Space, Navigation and Affect», in Diane Carr, David Buckingham, Andrew Burn and Gareth Schott (eds.), Computer Games: Text, Narrative and Play, Polity, Cambridge, pp. 59-71.

(2002): «Playing with Lara», in Geoff King and Tanya Krzywinska (eds.), ScreenPlay:cinema/videogames/interfaces, Wallflower Press, London, pp. 171-80.

CowIE, Elizabeth (1997): Representing the Woman: Cinema and Psychoanalysis, Macmillan Press, London.

Creed, Barbara (1993): The Monstrous-Feminine: Film, Feminism, Psychoanalysis, Routledge, London.

<http:/ /dx.doi.org/10.4324/9780203820513>

Egenfelt-Nielsen, Simon, Jonas Heide Smith, and Susana Tosca (2008): Understanding Video-Games: The Essential Introduction, Routledge, London. <http:/ /dx.doi.org/10.4324/9780203930748>

Fletcher, John (1995): «Primal scene and the female gothic: Rebecca and Gaslight», Screen, vol. 36, n. 4, pp. 341-370.

FrascA, Gonzalo (2003): «Simulation Versus Narrative: Introduction to Ludology», in Mark J. P. Wolf and Bernard Perron (eds.), The Game Theory Reader, Routledge, London, pp. 221-235.

Freud, Sigmund (1990): «The Uncanny», in The Penguin Freud Library, Volume I4 - Art and Literature, Penguin Books, London, pp. 339-76.

Freud, Sigmund (1991): «Beyond the Pleasure Principle», in The Penguin Freud Library, Volume II - On Metaphysiology: The Theory of Psychoanalysis, Beyond the Pleasure Principle, The Ego and the Id, and Other Works, Penguin Books, London, pp. 275-338.

GARde-HANSEN, Joanne (2011): Media and Memory, Edinburgh University Press, Edinburgh.

<http:/ /dx.doi.org/10.3366/edinburgh/9780748640348.001.0001>

GOLDBERG, Ruth (2004): «Demons in the family: tracking the Japanese "uncanny mother film" from A Page of Madness to Ringu», in Barry Keith Grant and Christopher Sharrett (eds.), Planks of Reason: Essays on the Horror Film, The Scarecrow Press, Oxford, pp. 370-385.

Grainge, Paul (2002): Monochrome Memories: Nostalgia and Style in Retro America, Praeger Publishing, London.

HAND, Richard J. (2004): «Proliferating horrors: survival horror and the Resident Evil franchise», in Steffen Hantke (ed.), Horror Film: Creating and Marketing Fear, University Press of Mississippi, Jackson, pp. 117-134.

Hirsch, Marianne (2002): Family Frames: Photography, Narrative and Postmemory, Harvard University Press, London.

Kaplan, E. Ann (1990): Psychoanalysis and Cinema, Routledge, London. <http:/ /dx.doi.org/10.4324/9780203873137>

Kilbourn, Russell J. A. (2010): Cinema, Memory, Modernity: The Representation of Memory from the Art Film to Transnational Cinema, Routledge, London.

<http:/ /dx.doi.org/10.4324/9781315888606> 
KING, Nicola (2000): Memory, Narrative, Identity: Remembering the Self, Edinburgh University Press, Edinburgh.

KIRKLAND, Ewan (2009): «Resident Evil's typewriter: horror videogames and their media», Games and Culture: A Journal of Interactive Media, vol. 4, n. 2 (2009), pp. 115-126.

KRZYWINSKA, Tanya (2002): «Hands on horror», in Geoff King and Tanya Krzywinska (eds.), ScreenPlay: cinema/videogames/interfaces, Wallflower Press, London, pp. 206-223.

LANDsberg, Alison (2004): Prosthetic Memory: The Transformation of American Remembrance in the Age of Mass Culture, Columbia University Press, New York.

Lury, Celia (1998): Prosthetic Culture: Photography, Memory and Identity, Routledge, London.

<http:/ /dx.doi.org/10.4324/9780203425251>

REHAK, Bob (2003): «Playing at being: psychoanalysis and the avatar», in Mark J. P. Wolf and Bernard Perron (eds.), The Video Game Theory Reader, Routledge, London, pp. 103-127.

SAntos, Marc C. and White, Sarah E. (2005): «Playing with ourselves: a psychoanalytic investigation of Resident Evil and Silent Hill», in Nate Garrelts (ed.), Digital Gameplay: Essays on the Nexus of Game and Gamer, McFarland, Jefferson, pp. 6979.

Sconce, Jeffrey (2005): Haunted Media: Electronic Presence from Telegraphy to Television, Duke University Press, London.

SKIrrow, Gillian (1986): «Hellivision: an analysis of video games», in Colin MacCabe (ed.), High theory/Low Culture: Analysing Popular Television and Film, Manchester University Press, Manchester, pp. 115-142.

Tews, Rebecca R. (2001): «Archetypes on acid: video games and culture», in Mark P. J. Wolf (ed.), The Medium of the Video Game, University of Texas Press, Austin, 2001, pp. 169-182.

WARner, Marina (2006): Phantasmagoria: Spirit Visions, Metaphors and Media into the Twenty-first Century, Oxford University Press, Oxford. 